\title{
Prehospitalno kašnjenje pacijenata sa znacima akutnog moždanog udara
}

Slavoljub R. Živanović

Gradski zavod za hitnu medicinsku pomoć Beograd, Srbija

\section{Pre-hospital delay in patients with signs of acute stroke}

Slavoljub R. Zivanovic

City Department of Urgent healthcare, Belgrade, Serbia

\section{Sažetak}

Uvod. Akutni moždani udar je drugi vodeći uzrok smrti i treći vodeći uzrok invaliditeta u svetu. Osnovni cilj u lečenju je da pacijent u prva 4,5h od pojave simptoma dobije trombolitičku terapiju. Većina pacijenata prve simptome doživi izvan zdravstvenih ustanova, tako da je važno prepoznavanje oboljenja od strane prisutnih osoba. Teži moždani udari, korišćenje vozila Hitne medicinske pomoći i mlađe životno doba udruženi su sa smanjenjem prehospitalnog kašnjenja.

Cilj rada. Prikazati koliko je prehospitalno kašnjenje pacijenata koji imaju tegobe koje ukazuju na moždani udar, i taj uticaj na lečenje.

Metod. Istraživanje je studija preseka rada ambulante Hitne medicinske pomoći Beograd u periodu od 1.1.2015. do 31.12.2018 god. sa pacijentima kojima je postavljena dijagnoza Cerebrovaskularni insult CVI, sumnja na CVI, Tranzitorni ishemični atak. Prehospitalno kašnjenje je vreme od pojave tegoba do trenutka javljanja lekaru. Pacijenti su podeljeni u grupe prema kašnjenju: do $3 h, 3-24 h$ i više od $24 h$. Statistička obrada je izvršena u programu SPSS 11, a statistička značajnost je definisana na nivou $\mathrm{p}<0,05$.

Rezultati. U istraživanju je učestvovalo 119 ispitanika prosečne starosti $65,53 \pm 14,24$ godina, muškog pola $46,22 \%$, ženskog pola $53,78 \%$. U prva tri sata od početka tegoba u ambulantu je stiglo 44,54\%, u vremenu od 3-24h - 31,93\%, a preko $24 h$ - 23,53\% pacijenata.

Zaključak. Više od polovine pacijenata se javlja u vremenu kada savremena trombolitička terapija nije efikasna.

Ključne reči: akutni ishemijski moždani udar, primarna zdravstvena zaštita, hitna medicinska pomoć

\section{Abstract}

Introduction. Acute stroke is the second leading cause of death and the third leading cause of disability in the world. The main goal of the medical treatment is to provide the patient with thrombolytic therapy within 4.5 hours from symptom onset. The majority of patients experience first symptoms outside of health facilities, so the recognition of the symptoms, by the people who are present, is of great importance. Severe strokes, using an ambulance, and younger age coincide with decreased pre-hospital delay.

Objective. We aimed to show how long is the pre-hospital delay of the patients with stroke symptoms and how it affects the patient's treatment.

Method. The research is a cross-sectional study of the ER, Belgrade, from 1.1.2015. to 31.12.2018. taking into account patients diagnosed with a stroke, suspected stroke, or TIA. Pre-hospital delay is a time from symptoms onset to the moment of seeing the physician. The patients were divided into three groups according to the delay time: up until $3 \mathrm{~h}$, $3-24 \mathrm{~h}$, and more than $24 \mathrm{~h}$. Statistical data processing was performed in SPSS 11 program, and statistical significance was defined at level $\mathrm{p}<0,05$.

Results. 119 participants took part in the study. Their average age was $65.53 \pm 14.24,46.22 \%$ were males, and $53.78 \%$ females. In the first three hours from the onset of the symptoms $44.54 \%$ of the patients arrived in the ER, $31.93 \%$ in $3-24 \mathrm{~h}$, and $23.53 \%$ arrived after $24 \mathrm{~h}$.

Conclusion. More than half of the patients come to ER in time when thrombolytic therapy is no longer effective. care 


\section{Uvod}

Akutni moždani udar (AMU) je drugi vodeći uzrok smrti i treći vodeći uzrok invaliditeta u svetu. Dužina trajanja i postupanja tokom prehospitalne faze je od velikog značaja za pacijenta1. "Osnovni cilj u lečenju AMU je da pacijenti u prva $4,5 h$ od pojave simptoma dobiju trombolitički terapiju da bi se smanjilo akutno ishemijsko oštećenje mozga, i da se obezbedi maksimalni oporavak bolesnika. Ovakav pristup podrazumeva tretiranje AMU kao bolest koja se leči po prvom stepenu hitnosti, gde faktor vreme postaje praktično najvažniji element uspešnosti lečenja"’2. Teži moždani udari-šlogovi, tj težina kliničke slike, korišćenje vozila Hitne medicinske pomoći i mlađe životno doba su udruženi sa smanjenjem prehospitalnog kašnjenja. Više od polovine kašnjenja je udruženo sa oklevanjem da se kontaktira medicinska služba ${ }^{3}$. Većina pacijenata prve simptome doživi izvan zdravstvene ustanove, što utiče na vreme kašnjenja. U radu Rose KM i sar. se navodi da čak $38 \%$ pacijenata imaju nepoznato vreme početka simptoma ${ }^{4}$. U Sjedinjenim Američkim Državama je oko 140.000 smrtnih ishoda godišnje uzrokovano CVI - cerebrovaskularni insult, odnosno, može se reći, svaki dvadeseti pacijent.

Pružanje hitne medicinske pomoći zahteva brzu dijagnostiku, zbrinjavanje i transport $u$ institucije sekundarne i tercijarne zdravstvene zaštite, što omogućava, između osta$\log$, i korišćenje protokola koji pomažu pri bržem i lakšem prepoznavanju simptoma i znakova. Intravenska tromboliza sa rTPA treba da se primeni u prva 4,5 sata od početka simptoma 5 . "Izgleda da ova terapija i posle $3 h(4 h-6 h)$ može imati povoljan efekat" ${ }^{\text {". }}$ Postoje pomaci u lečenju CVI, ali i neophodnost da se pacijenti na vreme jave lekaru da bi savremena terapija mogla biti primenjena.

Jedan od tri pacijenta sa difuznim MRI (Magnet Resonance Imaging) promenama i dokazanim AMU prvo zovu svog doktora porodične medicine. "Vizita licem u lice sa porodičnim doktorom učetvorostručuje šanse za prehospitalno kašnjenje" ". Naime, pacijenti su još uvek skloni da čekaju radno vreme svog lekara da prijave simptome TIA (tranzitorni ishemični atak). Problemi sa govorom, posebno dizartrija, povezani su sa kraćim kašnjenjem. Brigu zbog TIA simptoma treba ozbiljno shvatiti, štaviše populaciju putem medija od strane stručnjaka treba obučiti da shvate TIA kao hitnost $^{8}$. Kratko vreme između opažanja tegoba i stizanja u bolnicu poboljšava funkcionale ishode za pacijente sa infarktom mozga. Stoga, pacijenti moraju da se leče s minimalnim kašnjenjem posle dijagnoze ovog stanja ${ }^{9}$. Ako se posmatra šta su značajni predviđajući faktori prehospitalnog kašnjenja, onda pacijenti sa ruralnim prebivalištem ne shvataju svoje tegobe kao ozbiljne, ne dolaze u HP i doživljavaju moždani udar u budnom stanju. Ako bi građani bili obavešteni a time i zabrinuti oko prepoznavanja simptoma i neophodnosti ranog dolaska u tercijarni medicinski centar, smanjila bi se kašnjenja i povezana obolevanja. Pacijenti sa akutnim ish-

\section{Introduction}

Acute stroke is the second leading cause of death and the third leading cause of disability in the world. Pre-hospital time frames and procedures are of great importance for the patients ${ }^{1}$. "The main goal of the stroke treatment is to provide the symptomatic patients with thrombolytic therapy within first $4,5 h$ from the symptoms onset to lessen the acute (ischemic) brain damage and provide maximum patient recovery. This approach implies stroke should be treated as a disease with the first degree of urgency, where the time becomes the most important element of the treatment success"2. Severe strokes, or severe clinical presentations, using an ambulance and younger age coincide with decreased pre-hospital delay. More than half of the delays are due to the hesitancy of whether to contact medical help ${ }^{3}$. The majority of the patients experience first symptoms outside of healthcare facilities and it influences the delay. In the study of Rose $K M$ et al., it is shown that even $38 \%$ of patients have an unknown time of symptoms onset ${ }^{4}$. In the United States, 140.000 deaths/year are the consequnce of stroke, or in other words, every twentieth patient.

Providing urgent medical care requires fast diagnostics, medical care, and transport to the facilities of the secondary and tertiary healthcare levels. It provides, among other things, use of protocols that help with fast and easier recognition of the symptoms and signs. Intravenous thrombolysis with rTPA should be applied in the first 4,5h from the symptoms onset ${ }^{5}$. "It seems this therapy may have a favorable effect even after $3 h(4 h-6 h)^{\prime \prime 6}$ (Stroke guidelines 2004). There is progress in stroke treatment but also a necessity for the patients to seek medical help on time, so modern therapy could be applied.

One in three patients with diffuse MRI (Magnet Resonance Imaging) changes and proven stroke first call their family physician. "In- person visit to a family physician quadruplets the chance of pre-hospital delay"'. Apparently, patients still tend to wait for the opening time of their physician`s office to report the symptoms of TIA (transitory ischemic attack). Speech problems, especially disarthry, are connected with a shorter delay. Worry about TIA symptoms should be taken seriously, moreover, people should be educated by professionals, through media, to perceive TIA as an emergency ${ }^{8}$. A short time between signs observation and hospital arrival improves functional outcomes for stroke patients. Therefore, patients should be treated with minimal delay after the diagnosis has been made 9 . If we look at the consequential predictive factors of pre-hospital delay, we'll find that patients in rural settings often don't consider their symptoms seriously, don't come to ER, and have a stroke when they are awake. If people were educated, and therefore worried about recognizing symptoms and were aware of an absolute necessity to arrive early in the tertiary medical center, it would decrease the delay and consequential morbidity. Patients with acute 
emijskim moždanim udarom sa okluzijom velikih krvnih sudova, imaju koristi od direktnog transporta u specijalizovani centar za šlog opremljen za endovaskularno lečenje ${ }^{10}$. U svom radu Pulvers $J N$ i Watson JDG ističu da su srednje vreme i procenat pacijenata koji su došli u zdravstvenu ustanovu pre kritična tri sata, pokazali malo poboljšanje u poslednje dve decenije. Značajni faktori koji utiču na prehospitalno vreme su povezani s medicinskim putevima, simptomima moždanog udara, ponašanjem pacijenata i ljudi oko njih, pacijentovim karakteristikama i zabrinutošču zbog terapije ${ }^{11}$. Potrebno je obrazovanje građana da bi se ohrabrila rana poseta bolnici čak i kod pojave blagih simptoma AMU ${ }^{12}$. Denti $L$ i sar. kažu da njihova primenjena kampanja nije bila efikasna u smanjenju prehospitalnog kašnjenja i da treba testirati nove strategije komunikacije pre primene u velikim razmerama ${ }^{13}$. Faiz $K W$ i sar. smatraju da postoji suštinski jaz između znanja šta uraditi kod akutnog šloga; povećano znanje o šlogu nije udruženo s ranijim bolničkim prijemom ${ }^{14}$. Postoji i problem u samoj zdravstvenoj organizaciji, jer je " $60 \%$ onih koji su zbog svojih tegoba kontaktirali primarnu zdravstvenu zaštitu telefonom, upućeno na ambulantu lekara opšte medicine lično, što je dovelo do nepotrebnog kašnjenja"3. U našoj studiji, vreme dolaska pacijenata u ambulantu je samo deo prehospitalnog kašnjenja. Vreme transporta pacijenata iz ambulante do tercijarne ustanove koja je na manje od $1 \mathrm{~km}$ puta, uz obezbeđeno vozilo Hitne medicinske pomoći, manje je od $15 \mathrm{~min}-20 \mathrm{~min}$. U okviru Gradskog zavoda za hitnu medicinsku pomoć Beograd - ustanove primarne zdravstvene zaštite, radi ambulanta u režimu $24 \mathrm{~h} / 7$ dana sa mogućnošću javljanja građana sa zdravstvenim problemima bez zakazivanja. Preglede i pomoć ukazuju specijalisti opšte ili urgentne medicine. Postoje mogućnosti za dijagnostiku ECG, merenje glikemije, TA, ECG monitoring itd. Mali je broj istraživanja u okviru prehospitalne zdravstvene zaštite u oblasti rane dijagnostike i lečenja $\mathrm{CVI}^{15}$.

\section{Cilj rada}

Cilj rada je bio da se prikaže koliko je prehospitalno kašnjenje pacijenata koji imaju tegobe koje ukazuju/liče na moždani udar, kao i taj uticaj na lečenje.

\section{Metod}

Istraživanje je studija preseka rada ambulante GZHPM u periodu od 1. januara 2015 do 31 . decembra 2018. godine. Pri dolasku pacijenta u ambulantu otvara mu se elektronska datoteka u programu acces - bazi gde se upisuju svi podaci o njemu, kao i u papirni protokol. Podaci su dobijeni iz elektronskih datoteka koje sadrže osnovne podatke o pacijentu: vreme stizanja u ambulantu GZHMP, kao i glavne tegobe, početak tegoba, lična anamnezu, objektivni pregled, terapija stroke, with the occlusion of large blood vessels, would benefit from direct transportation to the specialized stroke center, equipped for endovascular treatment ${ }^{10}$. In their work, Pulvers $J N$ and Watson JDG stressed that median time and the percentage of patients who arrived in the hospital before critical three hours showed moderate improvement in the last two decades. The important factors that influence pre-hospital time are connected to medical pathways, stroke symptoms, patients ' behavior and people around them, patient's characteristics on their worry about getting therapy ${ }^{11}$. People should be educated to encourage an early visit to the hospital, even with mild stroke symptoms ${ }^{12}$. Denti $L$ and al. say their applied campaign wasn't as effective in decreasing pre-hospital delay, and new communication strategies should be tested before their application at large ${ }^{13}$. Faiz $K W$ and al. think there is a basic gap in the knowledge of what to do in an acute stroke; an increased knowledge on stroke is not connected to an early hospital admission ${ }^{14}$. There is also a problem in the healthcare organization itself, because " $60 \%$ of those who contacted primary healthcare by phone, due to their symptoms, were instructed to visit their family physician in person, which led to an unnecessary delay"'. In our study, the patient's arrival time at the ER is just part of the pre-hospital delay. Transportation time of the patient, with a provided ambulance, to the tertiary health facility, which is less than a kilometer away, is less than 15-20 minutes. In the City Department of urgent healthcare, Belgrade - which is a primary healthcare facility, there is an outpatient clinic, working $24 / 7$, and people with health problems may visit without prior appointment. The services are given by GP or Urgent care specialists. There are diagnostic possibilities such as ECG, checking glucose levels, $B P$, $E C G$ monitoring, etc. There is a small number of research papers in pre-hospital healthcare settings investigating early diagnosis and treatment of stroke ${ }^{15}$.

\section{Objective}

We aimed to show how long is the pre-hospital delay of the patients with symptoms of stroke and its effect on treatment.

\section{Method}

Our research is a cross-sectional study of the data gathered at the outpatient clinic of the City Department of urgent healthcare, from January, $1^{\text {st }} 2015$ to December, $31^{\text {st }} 2018$. On the patient's arrival to the outpatient clinic, his data are entered in EHR (Access program - database with all the necessary information about the patient). Data are also entered by hand in paper protocols. Our data were gathered from EHRs containing all the necessary information on a patient: arrival time at our clinic, as well as main complaints, symptoms 
i dalji postupci. Ako su podaci od strane pratilaca o početku tegoba bili pouzdani, uključeni su u istraživanje. Svim pacijentima je pored standardnog urađen i neurološki pregled. Pacijentu se potom iz elektronske datoteke štampa izveštaj koji ga prati kroz zdravstveni sistem. Za potrebe ovog rada korišćeni su podaci iz elektronskih datoteka sa nešto manjim brojem pacijenata nego u papirnom. Vreme kašnjenja je vreme od početka tegoba do trenutka stizanja u ambulantu. Pretraživane su dijagnoze CVI, CVI Suspecta (sumnja na CVI), TIA, to jest I63, G45 po MKB 10 (međunarodna klasifikaciji bolesti, deseta revizija). Iz programa acces podaci su izvezeni u excel datoteku gde je izvršeno sortiranje i filtriranje. Pacijenti su podeljeni u tri vremenske grupe: prehospitalno kašnjenje do tri sata kada bi trebalo da pacijent bez problema stigne na moguću trombolizu; od tri do $24 \mathrm{~h}$ i preko $24 \mathrm{~h}$ čekanja da se jave lekaru. Deskriptivna statistika urađena u spss verziji 11, rađen je $\chi 2$-test-kontingencije. Statistička značajanost je definisana na nivou 0,05 , podaci su prikazani grafički i tabelarno.

\section{Rezultati}

Od ukupno registrovanih 42.308 pacijenata, kod 153 pacijenta je postavljena dijagnoza CVI, CVI SUSP, TIA, što čini $0,36 \%$ ukupnog broja pacijenata. Sa upisanim vremenom za analizu bilo je 119 pacijenata i na njima je rađeno istraživanje. Prosek godina ispitivane grupe $\mathrm{No}=116$, $\chi^{2}=65,53 \pm 14,244$. Tri osobe muškog pola su bez upisanih godina starosti. onset, personal history, examination data, medications, and further measures. If the information by the accompanying persons on the symptoms onset was valid they were included in our research. All the patients had, besides the standard, a neurological examination as well. The patient's medical data are then printed and the report is given to the patient for his further consultations. For the purpose of our research, we used EHRs, with a little less number of patients, than in paper records. The delay time is the time from the symptoms onset to outpatient clinic arrival. We looked at diagnosis of stroke, suspected stroke, and TIA, or ICD 10 diagnosis I63, G45. From the Access program the data were entered in an excel database where we sorted and filtered them. The patients were divided into three time groups: pre-hospital delay up to three hours, in which time frame a patient should easily arrive for possible thrombolysis, from $3 h$ to $24 h$, and over $24 h$ delay before they saw the physician. Descriptive statistics were performed in SPSS 11 version, and the $\chi 2$-contingency test was performed. Statistical significance was defined for level 0,05. Data were shown in figures and tables.

\section{Results}

Out of 42.308 registered patients, 153 were diagnosed with a stroke, suspected stroke, or TIA, which makes $0,36 \%$ of the total number of patients. There were 119 patients with a reported time of the symptom onset, and they were included in our research. The average age of the participants $\mathrm{No}=116$ was $\chi^{2}=65.53 \pm 14.244$. Records of three male participants had no data on their age.

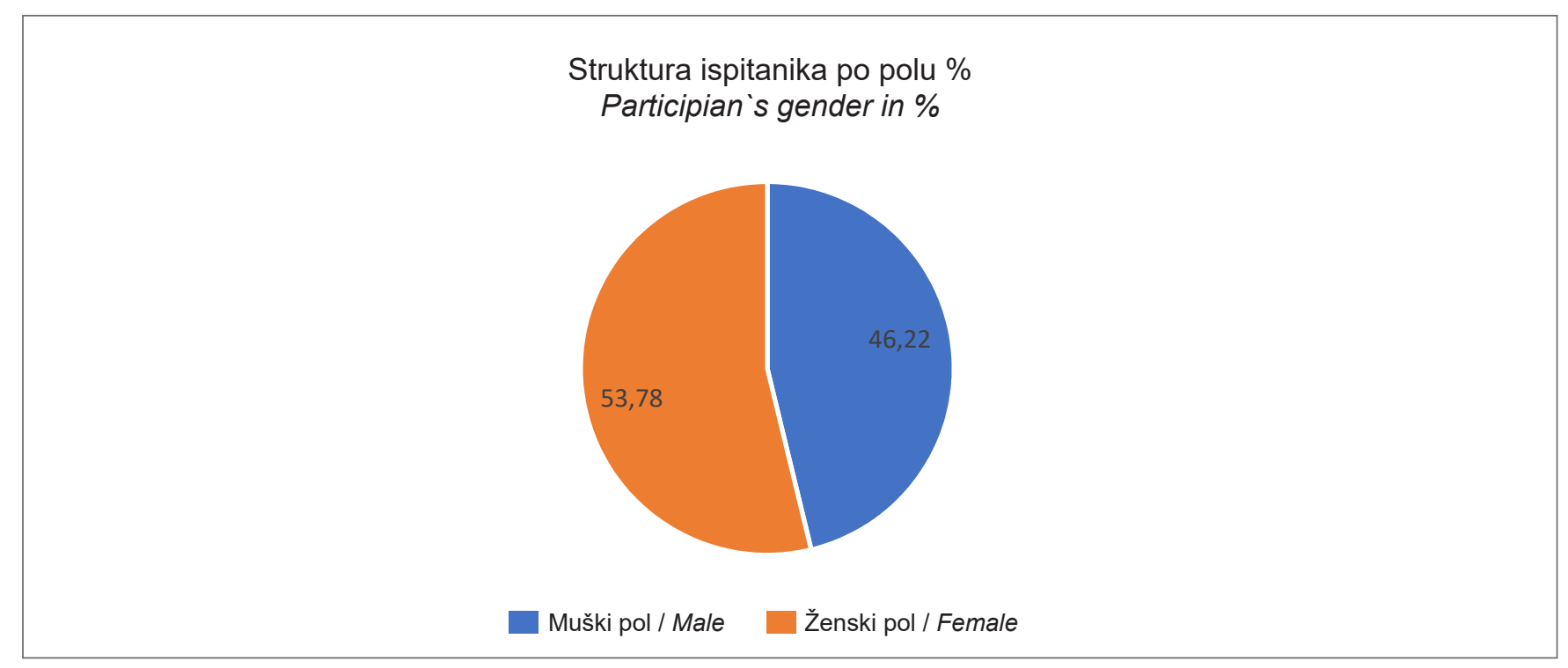

Grafikon 1. Struktura ispitanika po polu / Figure 1. Participant`s gender 
Bilo je 55 osoba muškog pola i 64 ženskog pola; $\chi^{2}=0,684588068, \quad \mathrm{p}>0,05, \quad$ nema statističke značajnosti $\chi^{2}=3,841-6,635 \mathrm{p}>0,05$.
There were 55 males and 64 females; $\chi^{2}=0.684588068$, $\mathrm{p}>0,05$, there was no significant statistical significance $\chi^{2}=3,841-6,635 \mathrm{p}>0,05$.

\section{Učešće ispitanika u \% Participian's age in \%}

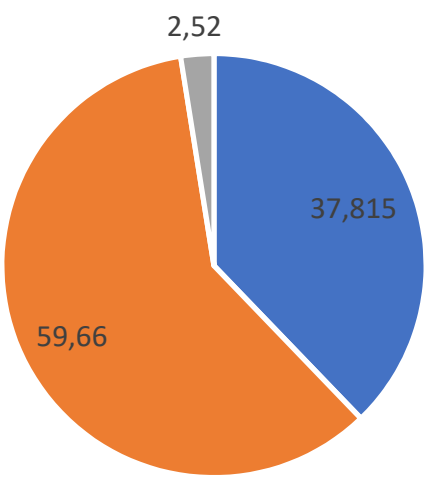

Do 65 godina / Up to 65 years
66 godina i više / 66years and older
Nepoznato / Unknown

Grafikon 2. Struktura ispitanika prema starosnom dobu - do 65 i preko 65 godina

Figure 2. The age structure of the participant's - up to 65 and over 65

Ukupno je bilo 119 ispitanika od 25 do 88 godia, tri osobe bez navedenih godina, $\chi^{2}=6,13, \mathrm{p}<0,05$.
There were 119 participants in total, ranging from 25 to 88 years, and three participants were of the unknown age, $\chi^{2}=6.13, \mathrm{p}<0,05$.

Tabela 1. Pacijenti podeljeni po polu i godinama, do 65 i preko 65 godina

Table 1. Patients 'distribution according to gender and age, up to 65 and over 65 years

\begin{tabular}{|l|c|c|c|}
\hline & N Muški pol/ N Males & N Ženski pol/ N Females & p= \\
\hline Svi ispitanici/ All participants & 55 & 64 & 0,68 \\
\hline Do 65 god./ Up to 65 years & 22 & 41 & 0,02 \\
\hline Preko 65 god./ Over 65 years & 30 & 5,75 \\
\hline Upoređenje po polu $\mathrm{p}=/$ Comparison by gender $\mathrm{p}=$ & 1,26 & 5,49 & \\
\hline Upoređenje po godinama $\mathrm{p}=/$ Comparison by age $\mathrm{p}=$ & 6,13 & 5,49 & \\
\hline
\end{tabular}

$\left(\chi^{2}=3,84-6,63\right)$ Tri muškarca bez upisanih godina (muški pol 46,22\%, ženski pol 53,78\%) $\mathrm{p}>0,05$

Do 65godina: 22 ispitanika muškog pola i 23 ženskog pola. $\chi^{2}=0,02$,

Preko 65 godina - 71 ispitanik, 30 muškog pola i 41 ženskog pola, $\chi^{2}=1,74, \mathrm{p}>0,05$.

Muški pol - 52 osobe, mlađi od 65 godina - 22, stariji od 66 godina $30, \chi^{2}=1,26, p>0,05$.

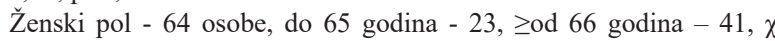
${ }^{2}=5,49, \mathrm{p}<0,05$. $\left(\chi^{2}=3.84-6.63\right)$. Three males had no records of their age (males $46,22 \%$, females $53,78 \%$ )

Up to 65 years: 22 male participants and 23 female participants. $\chi^{2}=$ $0.02, \mathrm{p}>0.05$ $\mathrm{p}>0.05$.

Over 65 years - 71 participants, 30 males and 41 females, $\chi^{2}=1.74$,

Males - 52 participants, under 65 years of age - 22, older than 66 years of age $-30, \chi^{2}=1.26, p>0.05$.

Females - 64 participants, under 65 years of age -23 , $\geq$ od 66 years of age $-41, \chi^{2}=5.49, \mathrm{p}<0.05$. 
Tabela 2. Prosek godina po vremenskim grupama, starosnim vremenskim grupama i polu

Table 2. Mean age by time groups, age-time groups, and gender

\begin{tabular}{|c|c|c|c|c|c|c|c|}
\hline $\begin{array}{c}\text { Vreme kašnjenja } \\
\text { Delay time }\end{array}$ & $\mathbf{N}$ & $\mathbf{\%}$ & $\begin{array}{c}\overline{\mathbf{x}} \text { godine } \\
\bar{x} \text { years of age }\end{array}$ & $\begin{array}{c}\text { \% osoba } \\
\text { muškog pola } \\
\text { \% male } \\
\text { participants }\end{array}$ & $\begin{array}{c}\text { \% osoba } \\
\text { zenskog pola } \\
\text { \% female } \\
\text { participants }\end{array}$ & $\begin{array}{c}\text { \% osoba } \\
\text { do 65 god. } \\
\text { \%articipants } \\
\text { up to 65. }\end{array}$ & $\begin{array}{c}\text { \% osoba } \\
\text { preko 65 god. } \\
\text { \% participants } \\
\text { over 65. }\end{array}$ \\
\hline $\begin{array}{c}\text { Cela grupa } \\
\text { Whole group }\end{array}$ & 119 & 100 & 65,53 & 46,22 & 53.78 & 38,79 & 61,21 \\
\hline $\begin{array}{c}\text { Do tri sata } \\
\text { Up to three hours }\end{array}$ & 53 & 44,54 & 63,85 & 43,396 & 56,60 & 43,4 & 56,60 \\
\hline $\begin{array}{c}\text { Do 24 sata } \\
\text { Up to 24 hours }\end{array}$ & 38 & 31,93 & 65 & 47,368 & 52,63 & 38,89 & 61,11 \\
\hline $\begin{array}{c}\text { Preko 24 sata } \\
\text { Over 24 hours }\end{array}$ & 28 & 23,53 & 69,36 & $50 \%$ & $50 \%$ & 28,57 & 71,43 \\
\hline Zbir & 119 & 100 & & & & & \\
\hline
\end{tabular}

Tri pacijenta muškog pola su bez upisanih godina. Upoređujući broj osoba u sve tri grupe, $\chi^{2}=3,43$, tj. bez statističke značajnosti $/ 3,84-6,63 / \chi^{2}=7,98 / 5,99-9,21 / \mathrm{p}<0,01 /$.

\section{Diskusija}

Prosek starosti naše ispitivane grupe je 65,53 godina, sa nešto većim učešćem ženskog pola i osoba starijih od 65 godina. Prehospitalno kašnjenje do tri sata je u $44,54 \%$ slučajeva, od $3 h$ do $24 h-31,93 \%$ a preko $24 h$ u $23,53 \%$ slučajeva. Što je duže prehospitalno kašnjenje raste prosek godina i veći udeo osoba muškog pola. Što je duže prehospitalno kašnjenje, veće je učešće osoba muškog pola starijih od 65 godina.

U radu Rose KM i sar. osobe ženskog pola čine $54 \%$ ispitivanih $^{4}$, u radu Emiš Vandlik i sar. se navodi nešto veći broj osoba ženskog pola ${ }^{16}$, takođe i u Kini je broj ispitivanih bolesnika sa sve većim udelom ženskog pola. U istraživanju u Kini više od $70 \%$ smrtnih ishoda od CVI se dešava kod osoba $\geq 65$ godina $^{17}$ (Grafikon 1 i 2). Rossnagel $K$ i sar. navode da postoji značajno prehospitalno kašnjenje od trenutka prvih simptoma do stizanja u zdravtsvenu ustanovu/Urgentni centar. Srednje vreme kašnjenja je bilo $151 \mathrm{~min}$. (5-9.590 $\mathrm{min}$.) i simptomi koji se smatraju urgentnim, bili su faktori najsnažije povezani sa prehospitalnim kašnjenjem, tj. kraćim vremenom ${ }^{18}$. Prema navodima u radu Ragoschke-Schumm i sar. manje od dva do sedam procenata pacijenata dobije odgovarajuće lečenje, jer najveći broj kasni sa početkom primene uspešne terapije ${ }^{19}$. $\mathrm{U}$ istražvanju sprovedenom u Kini, dobijeni su podaci o prehospitalnom kašnjenju u zbrinjavanju za 81,68\% pacijenata, što predstavlja statistički značajno izraženo kašnjenje u prehospitalnom zbrinjavanju pacijenata ${ }^{20}$. Srednje vreme pro-
Three male participants had no records of their age. Comparing the number of the participants in all three groups, $\chi^{2}=3.43$, there was no statistical significance $/ 3.84-6.63 / \chi^{2}=$ $7.98 / 5.99-9.21 / \mathrm{p}<0.01 /$.

\section{Discussion}

The average age of our participants was 65.53 , with slightly higher participation of female gender and persons over 65. Pre-hospital delay up to three hours was found in $44.54 \%$ of the cases, from $3 h$ to $24 h-31.93 \%$, and over $24 h$ in $23.53 \%$ of the cases. The longer the pre-hospital delay, the higher the average age of the participants and males share (males over 65).

In the work of Rose KM and al. females make 54\% of the participants ${ }^{4}$, Emiš Vandlik and al. also mention a bit higher number of females ${ }^{16}$, and in China as well, the number of the participants was with a higher share of the female gender. In the Chinese study, more than $70 \%$ of death outcomes, caused by stroke, occurred in persons $\geq 65$ years of age ${ }^{17}$ (Figure 1 and 2). Rossnagel $\mathrm{K}$ and al. say there is a significant pre-hospital delay from the onset of first symptoms to arrival in the hospital/ER. The mean delay time was 151 min. (5-9.590 min.) and symptoms considered urgent were the factors with the strongest connection to pre-hospital delay or shorter time ${ }^{18}$. According to Ragoschke-Schumm and al., less than $2-7 \%$ of patients get proper treatment because the largest number of them is late for the application of the successful therapy ${ }^{19}$. In the Chinese research, they got data on the pre-hospital delay in the treatment of $81.68 \%$ of patients, which is statistically significant ${ }^{20}$. The mean time to hospital 
teklo do stizanja u bolnicu je $27 \mathrm{~h}$, skoro polovina je stigla u okviru $24 h$, a $22,4 \%$ posle $72 h^{21}$. Samo $23 \%$ pacijenata je stiglo u okviru $2 h$ od početka simptoma ${ }^{4}$. Autori Dolmans $L S$ i sar. navode da je srednje vreme od početka simptoma do posete ustanovi za TIA zbrinjavanje bilo $114,5 h$, medijan kašnjenje 17,5h od preko $24 h$ u 38,7\% pacijenata. Postoji suštinsko kašnjenje pacijenta i lekara u procesu potvrde TIA dijagnoze, sa suboptimalnom prevencijom ranog ishemijskog šloga ${ }^{8}$. Giles $M F$, Flossman E i Rothwell PM u radu o TIA tvrde da je $44,4 \%$ pacijenata tražilo medicinsku pomoć u toku nekoliko sati, iako je samo mali broj njih bio u Emergency Departement/Zdravstvenom centru, $44.4 \%$ je zakasnilo da traži medicinsku pomoć za $\geq$ od jednog dana. Ispravno prepoznavanje simptoma u $42,2 \%$ pacijenta nije bilo udruženo sa smanjenjem kašnjenja. Pacijenti s motornim simptomima ili trajanjem simptoma $\geq 1 h$ bili su sa većom verovatnoćom da traže medicinsku pomoć. Kašnjenje nije povezano sa godinama, polom ili drugim vaskularnim faktorima rizika ${ }^{22}$. U radu Alurprakash $N$. i sar. srednje vreme kašnjenja je 13,6h. Pacijenti iz seoskih oblasti ne shvataju ozbiljno svoje simptome. Zabrinutost $\mathrm{u}$ narodu zbog prepoznavanja simptoma i rano stizanje $u$ tercijarne ustanove smanjilo bi kašnjenje i pridružena obolevanja ${ }^{23}$. U radu Schlemm L i sar. se kaže da rezultati sugerišu da pacijenti sa AIMU sa sumnjom na oklu ziju velikih krvnih sudova, treba preusmeriti u CSC (Comprehensive stroke center - Sveobuhvatni centar za moždani udar) ako je dodatno kašnjenje za intravensku trombolizu (IVT) manje od $30 \mathrm{~min}$. u gradskim i $50 \mathrm{~min}$. u seoskim uslovima ${ }^{10}$. Naše istraživanje je rađeno u glavnom gradu. Tabela 1. pokazuje da najveći broj pacijenata nije blagovremeno došao u Zdravstveni centar i nije mogao da bude uzet u obzir za savremenu trombolitičku terapiju. U radu Rose KM i sar. se kaže da je sveukupno srednje vreme od stizanja pacijenta u bolnicu do inicijalnog $C T$ skena (computer tomography) bilo $1,7 h$ a medijan vreme $1,2 h$. Među pacijentima koji su došli u roku od dva sata od početka simptoma u bolnicu, najvažniji nezavisni faktor za dolazak je bio dolazak vozilom $\mathrm{HMP}^{4}$, a i u našem istraživanju je više od polovine pacijenata bez mogućnosti terapije zbog vremenskog kašnjenja preko tri sata (Tabela 2).

Ograničenja studije: naše dijagnoze TIA, tj. CVI AIMU su radne, konačna dijagnoza se postavlja u zdravstvenoj ustanovi višeg nivoa sa mogućnošću neurovizualizacije tehnikama neuroimidžinga. U GZHMP nemamo mogućnost naknadne provere stanja pacijenta.

\section{Zaključak}

Više od polovine pacijenata se javlja u ambulantu zdravstvene ustanove u vremenu kada savremena trombolitička terapija nije efikasna. arrival was $27 h$, and almost half of them arrived within $24 h$, and $22.4 \%$ after $72 h^{21}$. Only $23 \%$ of patients arrived within $2 h$ from symptoms onset ${ }^{4}$. The authors Dolmans $L S$ and al. say the average time from symptoms onset to visiting the hospital for TIA treatment was $114.5 \mathrm{~h}$, median delay $17.5 \mathrm{~h}$, and over $24 h$ in $38.7 \%$ of patients. There is a fundamental delay in patients and physicians in confirming the TIA diagnosis with suboptimal prevention of an early ischemic stroke ${ }^{8}$. Giles MF, Flossman E, and Rothwell PM in their work on TIA claim $44.4 \%$ of patients sought medical help within a few hours, although a very few of them visited ER, 44.4\% were late to seek medical help for $\geq$ of one day. Correct symptoms recognition in $42.2 \%$ of patients didn't coincide with the shortening of the delay. Patients with motor symptoms or symptoms lasting $\geq 1 h$ were more likely to seek medical help. The delay is not connected with age, gender, or other vascular risk factors ${ }^{22}$. In the work of Alurprakash $N$. And al., the average delay time was $13,6 h$. Patients from rural areas do not take their symptoms seriously. If people worried more about symptoms recognition and early arrival in tertiary centers the delay would be lesser, as well as comorbidities ${ }^{23}$. In the work of Schlemm $L$ and al. is found that the results suggest the patients with stroke and suspected occlusion of major blood vessels, should be redirected to CSC (Comprehensive stroke center) if an additional delay for intravenous thrombolysis (IVT) is less than $30 \mathrm{~min}$. in urban and $50 \mathrm{~min}$. in rural areas ${ }^{10}$. Our research was conducted in the capital. Table 1. shows the largest number of patients didn't arrive on time in the ER, and therefore they couldn 't have been taken into account for a modern thrombolytic therapy. The work of Rose KM and al. found the total average time from patient's arrival to a hospital, to initial CT scan was $1,7 h$, and median time $1,2 h$. Among patients who arrived in the hospital within two hours from symptoms onset, the most important independent factor was coming by ambulance ${ }^{4}$, and in our research more than half of the patients couldn't get the proper therapy because of more than a three hour delay (Table 2).

Study limitations: our diagnosis of TIA, stroke are working diagnosis, and the final diagnosis is made in the higher level medical institutions, equipped with neuroimaging technics. In the City Department of urgent healthcare, we have no way to follow further patient care.

\section{Conclusion}

More than half of the patients arrive in outpatient clinics when modern thrombolytic therapy is no longer viable. 


\section{Reference/ Literatura}

1. Johnson W, Onuma O, Owolabi M, Sachdev S. Stroke: a global response is needed. Bull World Heal Organ. 2016;

2. Republička stručna komisija za izradu i implementaciju Vodiča dobre kliničke prakse, Srbije Ministarstvo zdravlja Republike Srbije. Nacionalni vodič dobre kliničke prakse za dijagnostikovanje i lečenje ishemijskog moždanog udara [Internet]. 2012 [cited 2020 Jul 14]. Available from: http://www. drustvoneurologasrbije.org/vodici/Vodic za dijagnostikovanje i lecenje ishemijskog mozdanog udara.pdf

3. Faiz KW, Sundseth A, Thommessen B, Rønning OM. Prehospital delay in acute stroke and TIA. Emerg Med J [Internet]. 2013 Aug [cited 2020 Jun 30];30(8):66974. Available from: https://pubmed.ncbi. nlm.nih.gov/22886891/

4. Rose KM, Rosamond WD, Huston SL Murphy CV, Tegeler CH. Predictors of time from hospital arrival to initial brain-imaging among suspected stroke patients: The North Carolina collaborative stroke registry. Stroke [Internet]. 2008 Dec 1 [cited 2020 Jun 30];39(12):3262-7. Available from: https://pubmed.ncbi.nlm. nih.gov/18688010/

5. Montiel-Luque A, Núñez-Montenegro AJ, Martín-Aurioles E, Canca-Sánchez JC, Toro-Toro MC, González-Correa JA, et al. Medication-related factors associated with health-related quality of life in patients older than 65 years with polypharmacy. Quinn TJ, editor. PLoS One [Internet]. 2017 Feb 6 [cited 2018 Dec 9];12(2):e0171320. Available from: http:// www.ncbi.nlm.nih.gov/pubmed/28166266

6. Ministarstvo zdravlja republike Srbije, repubička stručna komisija za izradu i implementaciju vodiča dobre kliničke prakse, Akutni ishemijski moždani udar. 2004. [Internet]. [cited 2020 Jul 14]. Available from: https://www.zdravlje.gov. $\mathrm{rs} /$ view_file.php?file id $=690 \&$ cache $=$ sr

7. Fladt J, Meier N, Thilemann S, Polymeris A, Traenka C, Seiffge DJ, et al. Reasons for Prehospital Delay in Acute Ischemic Stroke. J Am Heart Assoc [Internet]. 2019 Oct 15 [cited 2020 Jun 30];8(20). Available from: https://www.ahajournals. org/doi/10.1161/JAHA.119.013101

8. Dolmans LS, Hoes AW, Bartelink MLEL, Kappelle LJ, Rutten FH. Determinants of Patient Delay in Transient Ischemic Attack. Eur Neurol [Internet]. 2019 Aug 1 [cited 2020 Sep 22];81(3-4):139-44. Available from: https://pubmed.ncbi.nlm. nih.gov/31212275/
9. Seno S, Tomura S, Ono K, Akitomi $\mathrm{S}$, Sekine Y, Yoshimura Y, et al. The Relationship between Functional Outcome and Prehospital Time Interval in Patients with Cerebral Infarction. $\mathrm{J}$ Stroke Cerebrovasc Dis [Internet]. 2017 Dec 1 [cited 2020 Sep 22];26(12):2800-5. Available from: https://pubmed.ncbi.nlm. nih.gov/28774793/

10. Schlemm L, Endres M, Nolte CH. Bypassing the closest stroke center for thrombectomy candidates what additional delay to thrombolysis is acceptable? Stroke [Internet]. 2020 [cited 2020 Jun 30];51(3):867-75. Available from: https:// pubmed.ncbi.nlm.nih.gov/31964288/

11. Pulvers JN, Watson JDG. If time is brain where is the improvement in prehospital time after stroke? [Internet]. Vol. 8 , Frontiers in Neurology. Frontiers Media S.A.; 2017 [cited 2020 Jun 30]. Available from: https://pubmed.ncbi.nlm.nih. gov/29209269/

12. Yanagida T, Fujimoto S, Inoue T, Suzuki S. Prehospital delay and strokerelated symptoms. Intern Med. 2015 Jan 15;54(2):171-7.

13. Denti L, Caminiti C, Scoditti U, Zini A, Malferrari G, Zedde ML, et al. Impact on prehospital delay of a stroke preparedness campaign a SW-RCT (Stepped-Wedge Cluster Randomized Controlled Trial). Stroke [Internet]. 2017 [cited 2020 Jun 30];48(12):3316-22. Available from: https://pubmed.ncbi.nlm.nih. gov/29101258/

14. Faiz KW, Sundseth A, Thommessen B, Rønning OM. The knowing-doing gap in acute stroke-Does stroke knowledge translate into action? [Internet]. Vol. 9 , Brain and Behavior. John Wiley and Sons Ltd; 2019 [cited 2020 Jun 30]. Available from: https://pubmed.ncbi.nlm.nih. gov/30790476/

15. Shaw L, Price C, McLure S, Howel D, $\mathrm{McColl}$ E, Ford GA. Paramedic Initiated Lisinopril For Acute Stroke Treatment (PIL-FAST): Study protocol for a pilot randomised controlled trial. Trials. 2011 Jun 15;12:152.

16. Emiš-Vandlik N, Bogunović $\mathrm{S}$, GemišovNikolić F, Anđelić S. Prehospital diagnostic procedures in patients with acute ischemic stroke. Naučni časopis Urgent Med - Halo 194. 22(3):362-9.
17. Lu H, Guo Z, Liu J, Zhang H, Zhao W, $\mathrm{Wu} \mathrm{Y}$, et al. Trends in stroke incidence among elderly low-income residents of rural China: A population-based study from 1992 to 2016. Aging (Albany NY) [Internet]. 2018 Nov 1 [cited 2020 Feb 21];10(11):3438-49. Available from: http://www.ncbi.nlm.nih.gov/ pubmed/30487317

18. Rossnagel K, Jungehülsing GJ, Nolte CH, Müller-Nordhorn J, Roll S, Wegscheider $\mathrm{K}$, et al. Out-of-hospital delays in patients with acute stroke. Ann Emerg Med. 2004 Nov 1;44(5):476-83.

19. Ragoschke-Schumm A, Walter S, Haass A, Balucani C, Lesmeister M, Nasreldein A, et al. Translation of the "time is brain" concept into clinical practice: focus on prehospital stroke management. Int J Stroke [Internet]. 2014 Apr [cited 2020 Feb 11];9(3):333-40. Available from: http://www.ncbi.nlm.nih.gov/ pubmed $/ 24593156$

20. Jiang B, Ru X, Sun H, Liu H, Sun D, Liu Y, et al. Pre-hospital delay and its associated factors in first-ever stroke registered in communities from three cities in China. Sci Rep. 2016 Jul 14;6.

21. Fekadu G, Wakassa H, Tekle F. Stroke Event Factors among Adult Patients Admitted to Stroke Unit of Jimma University Medical Center: Prospective Observational Study. Stroke Res Treat [Internet]. 2019 [cited $2021 \mathrm{Jul}$ 4];2019. Available from: https://pubmed.ncbi.nlm. nih.gov/30854184

22. Giles MF, Flossman E, Rothwell PM. Patient behavior immediately after transient ischemic attack according to clinical characteristics, perception of the event, and predicted risk of stroke. Stroke [Internet]. 2006 May [cited 2020 Jun 30];37(5):1254-60. Available from: https://pubmed.ncbi.nlm.nih. gov/16574923/

23. Arulprakash N, Umaiorubahan M. Causes of delayed arrival with acute ischemic stroke beyond the window period of thrombolysis. J Fam Med Prim Care [Internet]. 2018 [cited 2020 Jun 30];7(6):1248. Available from: https:// pubmed.ncbi.nlm.nih.gov/30613505

Autori izjavljuju da nemaju sukob interesa Conflict of Interest: None declared

Primljen - Received - 11.07.2021. Ispravljen - Corrected - 08.10.2021. Prihvaćen - Accepted - 15.10.2021. 